
览脂漏性皮虐炎 (infantile seborrhoeic dermatitis)

はじめに

ヒトやヒト以外の哺乳動物の皮虐における常在菌であ るマラセチアは，時に癜風や毛囊炎の起因菌となり，さ らに脂漏性皮膚炎, アトピー性皮䖈炎などでは, 発症な いし増悪因子になっているものと考えられている1-5). しかし, 通常常在菌として皮虐に腐生的に存在するマラ セチアが，どのような機序により病原性を獲得し，これ らマラセチア関連疾患に関与していくのかは明確ではな い.いくつかのマラセチア関連疾患患者の病巣から分離 されるマラセチア属真菌について, 各種 Tween の資化 性等による同定法拉よび PCR 法による菌種同定をおこ ない，これらの疾患の起因菌種を検討したので結果を報 告する.

\section{I 各種 Tween の資化性等による同定}

\section{1. 対 象}

癜風患者 22 名 (男 16 , 女 6 , 年齢 $14 \sim 65$ 歳), 成人の 脂漏性皮虐炎 $(\mathrm{SD})$ 患者 42 名 (男 32 , 女 10 , 年齢 11 75 歳), 生後 1 力月の乳児脂漏性皮膚炎 (ISD) 患児 60 名（男 35，女25）の顔面から採取した 54 検体を対象と した.

2. 方 法

検体の採取は, 癜風患者, SD 患者は綿棒法, ISD 患者 についてはテープ法にて扔こなった. 被検部位について, 癜風患者は体幹の病変部, ISD 患者は顔面の病変部とし たが, SD 患者は, 同一人の病変部，健常部にかかわらず

別刷請求先: 中林 淳浩

邓227-8501 横浜市青葉区藤が丘 1-30 昭和大学藤が丘病院皮虐科
頭部, 顔面, 体幹からそれぞれ採取した. なお, SD と ISD の顔面病変については, 同様の方法で採取したコントロー ルを作成した，採取したこれらの検体を，Dixon 平板培 地に接種して $32^{\circ} \mathrm{C} て ゙$ 培養した. 得られたコロニーから， Guillotら6)の方法に従い, 各種 Tween の資化性, カタラー ゼ反応, 形態学的所見から菌種を同定した.

\section{3. 結 果}

癜風患者から分離された菌種は，M. globosa が圧倒的 に多く $12 / 22$ 例 (55\%) であった. その他 $M$. furfur, $M$. sympodialis, M. pachydermatis, M. slooffiae が分離された がいずれもごく少数であった（Table 1).

SD 患者の病変部からは $M$. globosa $21 \%, M$. furfur 21 \%が高率に分離されたが, SD患者の非病変部からもそ れぞれ $12 \%$ ，26\% 分離されており，この結果は，両者間 に有意差は見られなかった（Table 1)。しかし，SDの 顔面病巣での分離頻度と健常人顔面コントロールとの比 較では, $M$. globosa と $M$. furfur が SD において有意に高 率であった (Table 2).

ISD 患児の顔面病巣からの分離頻度は, M. globosa 41 \%, M. furfur 19\%で, M. sympodialis $9 \%$ であった.こ の結果は, M. furfur と M. globosa が健常児群コントロー ルより有意に高率である一方，M. sympodialis は健常児 群より明らかに低率であった（Table 3).

\section{PGR 法による同定}

\section{1. 対象と方法}

癜風患者 38名（男 29, 女 9, 年齢 18〜69歳）を対象 とし, 病変部をメスで擦過して極少量鱗屑を採取した. Makimura 57)の方法を用い菌種の同定をおこなった. 採取した鱗屑を鋳型として, ITS 1 特異的プライマーを 
Table 1. Number of isolated Malassezia species from patients with pityriasis versicolor (PV) and patients with seborrhoeic dermatitis (SD)

\begin{tabular}{|c|c|c|c|c|c|c|}
\hline \multirow{3}{*}{$\begin{array}{l}\text { Region } \\
\text { M. globosa }\end{array}$} & \multirow{2}{*}{\multicolumn{2}{|c|}{$\frac{\mathrm{PV}}{\text { Trunk }}$}} & \multicolumn{4}{|c|}{ SD } \\
\hline & & & \multicolumn{2}{|c|}{ Lesional skin } & \multicolumn{2}{|c|}{$\begin{array}{l}\text { Non-lesional } \\
\text { skin }\end{array}$} \\
\hline & 12 & $55(\%)$ & 10 & $21(\%)$ & 6 & $12(\%)$ \\
\hline M. furfur & 1 & 5 & 10 & 21 & 13 & 26 \\
\hline$M$. sympodialis & 2 & 9 & 3 & 6 & 6 & 12 \\
\hline M. pachydermatis & 1 & 5 & & & 4 & 8 \\
\hline \multicolumn{7}{|l|}{ M. obtusa } \\
\hline M. slooffiae & 1 & 5 & & & 1 & 2 \\
\hline M. restricta & & & & & 1 & 2 \\
\hline Negative culture & 3 & 14 & 15 & 31 & 10 & 20 \\
\hline Unknown/contamination & 2 & 9 & 10 & 21 & 9 & 18 \\
\hline No. of subjects & 22 & & 48 & & 50 & \\
\hline
\end{tabular}

Table 2. Comparison of number of isolated Malassezia species between healthy controls (HC) and patients with seborrhoeic dermatitis (SD) on face

\begin{tabular}{|c|c|c|c|c|c|}
\hline \multirow{2}{*}{ Region } & \multirow{2}{*}{\multicolumn{2}{|c|}{$\frac{\mathrm{HC}}{\text { Face }}$}} & \multirow{2}{*}{\multicolumn{2}{|c|}{$\frac{\mathrm{SD}}{\text { Face }}$}} & \multirow{3}{*}{$\begin{array}{c}\begin{array}{l}\text { Fisher's exact } \\
\text { method }\end{array} \\
\mathrm{P}<0.05\end{array}$} \\
\hline & & & & & \\
\hline M. globosa & 3 & $9(\%)$ & 5 & $22(\%)$ & \\
\hline M. furfur & 2 & 6 & 8 & 35 & $\mathrm{P}<0.05$ \\
\hline M. sympodialis & 1 & 3 & 1 & 4 & $P>0.05$ \\
\hline \multicolumn{6}{|l|}{ M. pachydermatis } \\
\hline \multicolumn{6}{|l|}{ M. obtusa } \\
\hline \multicolumn{6}{|l|}{ M. slooffiae } \\
\hline$M$. restricta & 1 & 3 & & & $\mathrm{P}>0.05$ \\
\hline Negative culture & 22 & 63 & 6 & 26 & \\
\hline Unknown/contamination & 6 & 17 & 3 & 13 & \\
\hline No. of subjects & 35 & & 23 & & \\
\hline
\end{tabular}

Table 3. Comparison of number of isolated Malassezia species between healthy infants (HI) and patients with infantile seborrhoeic dermatitis (ISD) on face

\begin{tabular}{|c|c|c|c|c|c|}
\hline \multirow{2}{*}{ Region } & \multirow{2}{*}{\multicolumn{2}{|c|}{$\frac{\mathrm{HI}}{\text { Face }}$}} & \multirow{2}{*}{\multicolumn{2}{|c|}{$\frac{\text { ISD }}{\text { Face }}$}} & \multirow{3}{*}{$\begin{array}{c}\begin{array}{l}\text { Fisher's exact } \\
\text { method }\end{array} \\
\mathrm{P}<0.05\end{array}$} \\
\hline & & & & & \\
\hline M. globosa & 7 & $15(\%)$ & 22 & $41(\%)$ & \\
\hline M. furfur & 2 & 4 & 10 & 19 & $\mathrm{P}<0.05$ \\
\hline M. sympodialis & 17 & 37 & 5 & 9 & $\mathrm{P}<0.05$ \\
\hline M. pachydermatis & 0 & & 0 & & \\
\hline M. obtusa & 0 & & 0 & & \\
\hline M. slooffiae & 0 & & 0 & & \\
\hline M. restricta & 1 & 2 & 0 & & $\mathrm{P}>0.05$ \\
\hline Negative culture & 22 & 48 & 20 & 37 & \\
\hline \multicolumn{6}{|l|}{ Unknown/contamination } \\
\hline No. of subjects & 46 & & 54 & & \\
\hline
\end{tabular}

用いて PCR をおこない，次にその PCR 産物を鋳型と して，各菌種の特異的プライマーを用いて，それぞれ Nested PCR をおこなった。

\section{2 . 結果 (Table 4)}

最も高率に検出された菌種は $M$. globosa で 37/38例（97 \%) であった. ついで, $M$. restricta 79\%, M. sympodialis 68\% の順で, M. pachydermatis \& $34 \%$ と比較的高率に認 められた。1 検体から平均 3 菌種検出された。

\section{考按}

瘄風の発症機序は, 局所の温度や湿度, 皮脂などが推
測されるがこれらの詳細は明確ではない. 最近，マラセ チア属は 7 菌種に再分類された ${ }^{8)}$. 我々は癜風病巣から の分離菌種を Tween 資化性により同定した結果，癜風 の起因菌種は, 新分類での M. globosa であろうと報告し た ${ }^{9)}$. Crespo ら ${ }^{10)}$ は96名の癜風患者病巣から分離され た菌種について，M. globosa が最多で $97 \%$ ，次いで $M$. sympodialis 32\%, M. slooffiae $7 \%$ と報告し, この結果より 起因菌を M. globosa と推測している.一方, Gupta ら ${ }^{11}$ は111名の癜風患者病巣からの分離菌種は, M. sympodialis が54.9\% と最も高率であり，次いで M. globosa $25.2 \%$, M. furfur $10.8 \%$ の順であると報告した. 継代培養された 
Table 4. Results of identification of Malassezia species from patients with pityriasis versicolor (PV) by the PCR method using the DNA sequences of nuclear ribosomal internal transcribed spacer 1

\begin{tabular}{lrc}
\hline \multicolumn{1}{r}{ Region } & \multicolumn{2}{c}{ PV } \\
\hline M. globosa & 37 & $97(\%)$ \\
$M$. furfur & 1 & 3 \\
M. sympodialis & 26 & 68 \\
M. pachydermatis & 13 & 34 \\
M. obtusa & 0 & \\
$M$. slooffiae & 7 & 18 \\
$M$. restricta & 30 & 79 \\
\hline No. of subjects & 38 & \\
\hline
\end{tabular}

株では, 培地での発育が遅い M. globosa の検出率が低下 するが9)，Gupta らの結果でM. globosa の分離頻度が低 い理由は，菌を同定する際に継代培養した菌を用いたた めと推測される.今回おこなった PCR 法は，鋳型とし て病変部の鱗首を直接用いて扔り，培養された菌による 同定方法と異なり，鱗首中に含まれる複数の菌種を検出 することが可能であったと思われる. 38 例中 37 例とほ とんど全ての癜風患者から $M$. globosa が検出された今回 の PCR 法の結果は, M. globosa が曒風の起因菌であろ うという我々の報告9)を裏付けるものであった．さらに 多くの例では 1 検体から M. globosa 以外の複数の菌種が 検出され，特にM. restricta，M. sympodialis などが高率で あった. 今後は $M$. globosa がどのような機序で発症に関 わるのか，また，その他の菌種の関与なよ゙が険討課題と なるであろう。

脂漏性皮膚炎は，頭部，顔面などの脂漏部位に，鱗屑 を付した病変をみる疾患であり, 思春期以降に発症し慢 性に経過する成人の脂漏性皮虐炎と, 生後 $2 \sim 6$ 週頃に 発症, 数週ないし $2 \sim 3$ 力月で自然消退する乳児脂漏性 皮膚炎がある。成人の脂漏性皮膚炎では，病巣に多数の マラセチアが存在することや抗真菌㓮が有効であること などから，本症へのマラセチアの関与が考えられている 1-3).ささらに, ISD も病変部にマラセチアが多く存在し, 抗 真菌剤が奏功するとの報告 ${ }^{12-15)}$ があり，関与が推測され る. SD, ISD ともに正常人に比べ $M$. globosa，M. furfur が高率に検出されたTween 資化性による同定方法の結 果は，この 2 菌種が関与することを示唆している。しか し, 病巣部におけるすべての菌種を明らかにはできない Tween の資化性による同定法の結果をもって, 本症の起 因菌種の確定に至ったとは言い難く，今後さらなる検討 が必要と考えられる。

$$
\text { 謝辞 }
$$

本研究を行うにあたり，菌種の同定法についてご指導 いただきましたJacques Guillot 博士，PCR 法について
ご指導いただきました槙村浩一博士に深謝申し上げます。

$$
\text { 文献 }
$$

1) Faergemann J: Seborrhoeic dermatitis and Pityrosporum orbiculare: Treatment of seborrhoeic dermatitis of the scalp with miconazole-hydrocortisone (Daktacort), miconazole and hydrocortisone. Br J Dermatol 114: 695-700, 1986.

2) Bergbrant I-M: Seborrhoeic dermatitis and Pityrosporum ovale: cultural, immunological and clinical studies. Acta Dermatol Venereol 71 (Suppl): 1-167, 1991.

3) Sei $Y$, Hamaguchi $T$, Ninomiya $J$, Nakabayashi $A$, Takiuchi I: Seborrhoeic dermatitis: Treatment with antimycotic agents. J Dermatol 21: 334-340, 1994.

4) Waersted A, Hjorth N: Pityrosporum orbiculare- a pathogenic factor in atopic dermatitis of the face, scalp and neck? Acta Dermatol Venereol 114 (Suppl): 146-148, 1985.

5) Wessels MW, Doekes G, et al: IgE antibodies to Pityrosporum ovale in atopic dermatitis. Br J Dermatol 125: 227-232, 1991.

6) Guillot J, Guého E, Lesourd M, Midgley G, Chévrier G, Dupont B: Identification of Malassezia species, A practical approach. J Mycol Med 6: 103-110, 1996.

7) Makimura K, Tamura Y, Kudo M, Uchida K, Saito H, Yamaguchi H: Species identification and strain typing of Malassezia species stock strains and clinical isolates based on the DNA sequences of nuclear ribosomal internal transcribed spacer 1 regions. J Med Microbiol 49: 29-35, 2000.

8) Guého E, Midgley G, Guillot J: The genus Malassezia with description of four new species. Antonie van Leeuwenhoek 69: 337-355, 1996.

9) Nakabayashi A, Sei Y, Guillot J: Identification of Malassezia species isolated from patients with seborrhoeic dermatitis, atopic dermatitis, pityriasis versicolor and normal subjects. Med Mycol 38: 337-341, 2000.

10) Crespo V, Ojeda A, Vera A, Crespo A, Sanchez F: Malassezia globosa as the causative agent of pityriasis versicolor. Br J Dermatol 143: 799-803, 2000.

11) Gupta AK, Kohli Y, Summerbell RC, Faergemann $\mathrm{J}$ : Epidemiology of Malassezia yeasts associated with pityriasis versicolor in Ontario, Canada. Med Mycol 39: 199-206, 2001.

12）中林淳浩, 清 佳浩: 乳児脂漏性皮䖉炎におけるマラセチ ア属真菌の関与について. 日小皮会誌 20: 127-131，2001.

13) Ruiz-Maldonado R, Lopez-Matinez R, Chavarria P, Castanon L, Tamayo L: Pityrosporum ovale in infantile seborrhoeic dermatitis. Pediatr Dermatol 6: 16-20, 1989.

14) Broberg A, Faergemann J: Infantile seborrhoeic dermatitis and Pityrosporum ovale. $\mathrm{Br} \mathrm{J}$ Dermatol 120: 359-362, 1989.

15) Taieb A, Legrain V, Palmier C, Lejean S, Six M, Maleville J: Topical ketoconazole for infantile seborrhoeic dermatitis. Dermatologica 181: 26-32, 1990. 


\title{
Identification of Causative Species in Malassezia-Associated Dermatoses
}

\author{
Atsuhiro Nakabayashi \\ Department of Dermatology, Showa University Fujigaoka Hospital \\ 1-30 Fujigaoka, Aoba-ku, Yokohama 227-8501 Japan
}

The Tween test was used to identify Malassezia species isolated from patients with pityriasis versicolor and seborrhoeic dermatitis, and suckling infants with seborrhoeic dermatitis. The most common species isolated from cases of pityriasis versicolor was $M$. globosa $(55 \%)$, and this species was surmised to be the principal causative organism of this disease. In both adult and suckling infant cases of seborrhoeic dermatitis, $M$. globosa and $M$. furfur were isolated at high incidences compared with the healthy control subjects, indicating the possibility that one or both of these species are the causative organisms of these diseases.

In addition, scales were collected from lesions of pityriasis versicolor for use as the template, and the involved Malassezia species were identified by the PCR method using the DNA sequences of nuclear ribosomal internal transcribed spacer 1 . The most commonly detected species was $M$. globosa, found in $97 \%$ of the cases, and this was followed in frequency by $M$. restricta (79\%) and M. sympodialis (68\%). It was also elucidated that multiple Malassezia species can be detected in the same specimen. 